\title{
Continued food aversion: Training livestock to avoid eating poisonous plants
}

\author{
MICHAEL H. RALPHS
}

Author is range scientist, USDA/ARS Poisonous Plant Lab. 1150 E, 1400 N, Logan, Utah 84321.

\begin{abstract}
Animals can be trained to avoid eating specific foods by offering them the food and subsequently administering an emtic to induce nausea. The animal associates the taste of the food with the induced illness and subsequently avoids eating that food. Conditioned food aversion (CFA) is a potential tool to prevent livestock poisoning from palatable and abundant poisonous plants. Cattle have been trained to avoid eating tall larkspur (Delphinium barbeyi L. Huth), a particularly troublesome poisonous plant. However, several factors influence the acquisition and retention of food aversions under field grazing conditions. The age and sex of an animal may influence its ability to form and retain aversions. Novelty of the plant and the intensity of the induced illness determine the strength of the aversion. Social facilitation or peer pressure motivates animals to sample the averted food, and the aversion will extinguish if it is not reinforced. Generalizing the aversion created under controlled conditions in a pen, to a complex vegetation community in the field, may be difficult for some animals. If these obstacles can be overcome, CFA may be an effective tool to reduce the risk of poisoning on poisonous plant infested rangeland.
\end{abstract}

Key Words: food aversion, poisonous plants, Delphinium barbeyi, livestock grazing

Animals learn preferences for foods (Provenza et al. 1990). We can refine their learning process and teach them to avoid eating specific troublesome poisonous plants through the process of contitioned food aversion (CFA). The process is fairly simple: animals are offered a food, they smell it, eat it, and then are given an emetic to induce nausea. An association is made between the taste of the food and the induced illness, and the animal will subsequently refuse that food.

Controlled conditions are generally required where a single feed is ingested and associated with the induced illness. For this, reason natural aversions to many poisonous plants are not likely because large generalist herbivores graze many plants over an extended feeding period and are not likely to associate an illness with a particular plant (Zahorik and Houpt 1977). There is evidence, however, that native animals are less likely to be poisoned than are newly introduced animals (Everist 1981, Provenza et al. 1990), which suggests that animals may form some natural aversions through trial and error learning.

Conditioned food aversion is more than the animal recognizing the specific food that made it sick and subsequently avoiding it (Pelchat and Rozin 1982). There is a hedonic shift or a change in palatability, making that food distasteful. The neural convergence theory suggests that afferent nerves of the olfactory, gustatory, visceral systems converge in the emetic centers of the midbrain and brain stem. If illness information is conveyed by the visceral system along the same pathway recently activated by the olfactory and

Manuscript accepted 28 May 1991. gustatory system, flavor-illness associations are formed (Garcia et al. 1985). The animal need not be conscious during the association, since aversions are readily formed in anaesthetized and unconscious animals (Bermudez-Rattoni et al. 1988). Aversions can also be formed with emetic doses low enough that overt signs of nausea are not apparent. The hedonic shift suggests that the food no longer "tastes good" and the animals avoid eating it.

Since food aversions are easy to establish (a single pairing of a flavor with an induced illness will form a strong aversion to that flavor), CFA has been used as a model to elucidate principles of learning (Braveman and Bronstein 1985). There has been limited application of CFA to reduce coyote and wolf predation on livestock and rodent depredation on crops (Gustavson and Gustavson 1985), in treatment of alcoholism (Nathan 1985) and eating disorders (Logue 1985), and in preventing anorexia in cancer patients treated with chemotherapy or radiology (Bernstein 1985).

Zahoric and Houpt $(1977,1981)$ were the first to try CFA on livestock and found that cattle, sheep, goats, and horses are able to form food aversions under controlled conditions. Provenza and his associates (1987) have developed principles of both positive and aversive conditioning of sheep under pen feeding and pasture grazing conditions. Our early research demonstrated that cattle have the neurophysiological mechanisms to form and retain food aversions over extended periods (Olsen and Ralphs 1986).

Conditioned food aversion is a potential tool to prevent livestock from ingesting poisonous plants that are palatable, abundant, and cause persistent poisoning problems (i.e., larkspur, lupine, locoweed, timber milkvetch, bitterweed, death camas, and ponderosa pine needles). CFA will probably not be effective on poisonous plants that are unpalatable, or occur sporadically in space or time. The extenuating circumstances which force livestock to eat unpalatable poisonous plants (overgrazing, drought, storms) would likely overcome the aversion.

I will illustrate the process of creating an aversion to tall larkspur (Delphinium barbeyi L. Huth), and our attempts to maintain the aversion in field grazing situations. I will discuss some of the principles and obstacles which must be overcome to maintain aversions in a complex vegetative community, and in a social context of grazing within a herd. I will conclude with several recommendations for future research needed to resolve these obstacles in order to make CFA a practical management tool.

\section{Averting Cattle to Tall Larkspur}

We selected tall larkspur as a prototype to determine if aversion could be created and reduce the incidence of poisoning. Tall larkspur is the most important poisonous plant problem on mountain cattle ranges. It is a native pristine species that grows in dense patches on snow-drift sites in big sagebrush, aspen, and subalpine plant communities. It is both palatable and acutely toxic to cattle and causes persistent losses ranging up to $10 \%$ in some herds. Cattle apparently do not form natural aversions to larkspur (Marsh and Clawson 1916, Pfister et al. 1988), and other manage- 
ment alternatives are limited.

Yearling Hereford heifers that had grazed on larkspur-infested rangeland as calves were purchased and trained to eat in selflocking stanchions. Fresh larkspur plants collected in the field were offered to the heifers. Prior to the offering, blind rumen fistulae were installed in each animal through which a catheter was inserted into the rumen. A tube was attached to the catheter to infuse the emetic directly into the rumen while the animal was eating the plant, to avoid any association between the induced illness and the handling process or taste of the emetic. If the heifer consumed any amount of larkspur, she was dosed intraruminally with lithium chloride $(\mathrm{LiCl})$ at a rate of $100 \mathrm{mg} / \mathrm{kg}$ body weight, in an $8 \%$ isotonic solution. Regular feed was withheld for the remainder of the day to avoid any interference between the taste of larkspur and the illness. This procedure was repeated at 2-or 3-day intervals for a total of 5 offerings. Total aversion to larkspur was obtained following 2 or 3 infusions of $\mathrm{LiCl}$ in the pen feeding trial (Olsen et al. 1989).

The averted group and nonaverted control heifers were then taken to the field to larkspur-infested rangeland. The 2 groups were placed in separate but adjacent pastures and diets were quantified by bite count. The aversion to larkspur persisted in the conditioned group while the control heifers ate larkspur for up to $25 \%$ of their diets (Lane et al. 1990). The averted heifers were held over to the next year and returned to the mountain pasture to see if the aversion would persist. They abstained from eating larkspur while they remained in a separate pasture.

The next part of the experiment determined if the aversion would persist in a mixed group grazing situation with other heifers that were avidly eating larkspur. The averted heifers abstained for the first part of the grazing period. However, as they socialized with the control heifers, they began to sample larkspur. When negative consequences were not forthcoming, they continued to eat and the aversion eventually extinguished (Lane et al. 1990). We concluded that social facilitation (peer pressure) has a very strong influence on foods animals will sample.

We next sought to strengthen the aversion in an effort to overcome the effects of social facilitation (Ralphs and Olsen 1990). A new group of heifers were averted to larkspur and were then subjected to peer pressure of nonaverted heifers eating larkspur in controlled pen feeding trials. They were infused with $\mathrm{LiCl}$ whenever they sampled larkspur in the group feeding trial. We further increased the social pressure by feeding larkspur in the common manger with all averted and nonaverted heifers competing for the food. The averted heifers maintained the aversion under this severe pressure for $\mathbf{4}$ days. On the last day of the trial, 2 averted heifers took a few bites and were treated with $\mathrm{LiCl}$. These heifers learned that even though other animals ate larkspur, they would get sick if they tried it.

The strengthening procedure was successful in maintaining the aversion in a group feeding situation while the heifers remained in the pen environment similar to the one in which the aversion was created. However, when the heifers were taken to the field, the aversion extinguished as they grazed with nonaverted heifers. These heifers were unfamiliar with the mountain grazing environment and the aversion was not strong enough to withstand peer pressure in a new environment.

When the heifers were returned to the pen (the original environment where the aversion was created), the aversion resumed, and 3 of 4 heifers refused to eat larkspur in the group feeding situation. Food aversions are more likely to be expressed in environments similar to where they were created. Generalizing aversions to different environment (i.e., the field) may be difficult, particularly for animals not familiar with the grazing environment.

\section{Factors Affecting Persistence of Aversions}

Although aversions are easy to establish, we found they are sometimes difficult to maintain. Aversions depend on the hedonic value or palatability of a food. Unfortunately, palatability is not a fixed property, but varies according to experience and physiological state of the animal (Garcia et al. 1977, Galef 1988). Subtle differences in plant chemistry and/or phenology may also alter the odor/taste of the plant, thus changing its attractiveness to the animal. Sampling a food without adverse consequences will positively shift the hedonic value of that food and rapidly extinguish an aversion (Logue 1985, Garcia et al. 1956). Thorhallsdottir et al. (1987) averted lambs to different feeds by mixing the emetic in the food. However, the aversion was never complete, and lambs continued to sample small amounts of the tainted feed at subtoxic levels. When the emetic was removed, consumption of the feed increased. Unless the toxin is an indigenous component of the food, the aversion must be complete to prevent sampling.

\section{Learning Ability}

The ability to learn is as varied among animals as it is in humans. Smith (1985) discussed the variability of rats to learn and retain aversions to saccharine solutions. Some extinguished the aversion rapidly, while others retained it over the 15-day trial. Smith concluded that rats differ in their sensitivity to either the taste cue of the food, the intensity of illnes induced by the emetic, or their ability to learn the taste and illness relationship.

\section{Drugs}

Any chemical or physiological state which affects the upper gastrointestinal tract or the emetic center of the brain can serve as the unconditioned stimulus in creating an aversion (Garcia and Holder 1985). Riley and Tuck (1985) reviewed the literature and listed 56 drugs (including some toxins) which have been effective in creating aversions. Lithium chloride $(\mathrm{LiCl})$ is widely used in behavioral studies with animals and in human clinical applications. It causes nausea without dangerous side effects. The method of administering $\mathrm{LiCl}$ (mixed in food, gavaged, subcutaneous or intrapartiniel injections) appear equally effective in creating an aversion (Nachman and Ash 1973, Shumake et al. 1982). Cyclophosphamide and thiabendazole are also commonly used to create aversions. Irradiation with low level radiation treatments was used extensively in the past to cause nausea in aversion trials. We also experimented with larkspur alkaloids as the emetic agent and found they were as effective as $\mathrm{LiCl}$ in creating an aversion to alfalfa pellets in cattle (Olsen and Ralphs 1986). However, natural aversions to larkspur are generally not formed because of the difficulty of associating illness to a particular plant among many, which animals consume during an extended grazing period.

\section{Dose}

The strength of the aversion and its resistance to extinction varies with the intensity of the induced illness (Dragoin 1971, Testa and Ternes 1977). The intensity of the induced illness creates feedback to the brain and is associated with the taste of the food. Increasing doses of $\mathrm{LiCl}$ (increasing intensity of illness) increased the strength and retention of aversions in rats and sheep (Nachman and Ashe 1973, du Toit et al. 1990). Total aversion was obtained from doses of 130 and $150 \mathrm{mg} / \mathrm{kg}$ body weight respectively. Shumake et al. (1982) created aversions in wild Philippine rats using $\mathrm{LiCl}$ at 36,105 , and $375 \mathrm{mg} / \mathrm{kg}$ body weight. The aversion extinguished in the groups given 36 and $105 \mathrm{mg} / \mathrm{kg}$, but the aversion persisted over the 28-day trial in the group given $375 \mathrm{mg} / \mathrm{kg}$. The lethal dose of $\mathrm{LiCl}$ to cattle lies somewhere between 250 and 500 $\mathrm{mg} / \mathrm{kg}$ body weight (Johnson et al. 1980). Although aversions can be formed with low doses of emetics, higher levels which create intense illness are required to maintain long lasting aversions. 


\section{Taste Cue}

Novelty and intensity of the taste cue (conditioned stimulus) are also important in acquiring and retaining an aversion (Testa and Ternes 1977, Nachman et al. 1977, Rozin and Kalat 1971). Taste elicits the orienting response to a new food (Garcia 1989). Therefore, the more novel or unique the taste, the stronger is its association with the induced illness (Best and Barker 1977).

It is difficult to form aversions to familiar foods. Foods that have not caused harm in the past are not expected to do so, and fall into a "learned safety" status (Kalat and Rozin 1973). The learned safety status must be "unlearned" or overcome to form an aversion. As little as 1 lengthy exposure or several short exposures to a food prior to pairing it with an emetic is detrimental to forming an aversion (Best and Barker 1977). Several pairings of taste with illness are required to form aversions to familiar foods, and aversions that do form extinguish more rapidly (Fenwick et al. 1975, Olsen and Ralphs unpublished data).

The food must be ingested to form an association with illness. The odor of the food, or mere tasting it without ingestion is not sufficient to form an aversion (Revusky et al. 1976, Domjan and Wilson 1972). However, the smell, followed by taste and subsequent ingestion, forms a strong compound stimulus which is associated with the illness. Thereafter, the smell alone is sufficient to cause the animal to avoid the food without having to taste it.

Aversions can be formed with long delays (up to 12 hours) betwen the taste cue and the induced illness (Garcia et al. 1966); however, aversions are stronger when the cue and consequence are in close proximity. The strength of the aversion declines when the interval goes beyond about 4 hours (Burritt and Provenza 1990a, Andrews and Braveman 1975).

\section{Hunger}

Food deprivation prior to conditioning has little direct influence on forming aversions (Revusky et al. 1980). Hungry animals may eat more during conditioning, thus enhancing the flavor stimulus (Braveman and Crane 1977).

On the other hand, hunger during testing or extinction trials can reduce the strength of the aversion (Grote and Brown 1973, WelIman and Boissard 1981). Hungry animals eat even though the food has been associated with illness and "tastes" bad. Sampling without adverse consequences will rapidly extinguish the aversion. A choice of 2 foods during testing eliminates the forced consumption of the averted food, and thus is a more sensitive measure of the aversion (Grote and Brown 1973, Dragoin 1971). A single food test is a severe test of the aversion.

Animals are also likely to sample foods that are constantly available to them (Zajonc 1968). Offering an averted food intermittently in test trials is more likely to preserve the aversion than offering the food free choice.

\section{Social Facilitation}

Galef (1988) defined social facilitation as "the initiation of a particular response, already in an animal's repertoire, when shown in the presence of others engaging in that behavior."Zajonc (1965) described it as the sights and sounds of others doing the same thing, which augments the ongoing response. Social facilitation has been the most important factor inhibiting the retention of an aversion to larkspur in our mixed grazing trials. Burritt and Provenza (1989) also reported that some lambs extinguished aversions to mountain mahogany when grazing in the presence of nonaverted lambs.

Several other studies report the influence of social facilitation in extinguishing aversions. Thorhallsdottir et al. (1990a) averted lambs and ewes to calf manna ${ }^{R}$. When offered only calf manna ${ }^{R}$ (no choice of feeds), both lambs and ewes extinguished the aversion. The ewes appeared to be more resistant to social facilitation when a choice of feed was offered. Gustavson and Gustavson (1985) reported that raccoons preying on chickens could be averted when they consumed dead chickens containing $\mathrm{LiCl}$. The aversion effectively generalized to live chickens and persisted for 8 months. However, during that time, kits were born and matured. When the kits were exposed to live chickens, the kits killed the chickens and began eating them. Within $30 \mathrm{~min}$, the averted adults began eating the chickens, and subsequently returned to killing chickens. Galef (1986) reported that rats made nauseous after eating a novel food, ate substantial amounts of the averted food following interaction with conspecifics which had eaten that food. He concluded that "rats will abandon, to a greater or lesser extent, reliance on information it personally has collected concerning the value of potential foods, in favor of information acquired from others." In rats, humans, and other animals, social influence is an important determinant of diet selection (Rozin and Zellner 1985). Thus, aversions are likely to be difficult to maintain in a mixed group feeding or grazing situation.

\section{Age}

Learning ability varies with age. Livestock may learn to forage most efficiently around the time of weaning (Provenza and Balph 1988). Thereafter, acceptance of new foods declines as animals mature (Squibb et al. 1990). However, the inquisitive character of young animals in sampling new foods may be a liability in maintaining an aversion. For example, weanling and preweanling rats form weaker aversions and extinguish faster than adults (Guanowsky et al. 1983, Steinert et al. 1980, Springer and Fraley 1981, Franchina and Horowitz 1982). Several possibilities have been suggested for the inability of young rats to retain aversions. Anatomical, chemical, and physiological development of the central nervous system is not complete until around the time of weaning. Therefore, young rats may have difficulty encoding taste and illness stimuli, associating effects, and withholding appropriate behaviors (Franchina and Horowitz 1982). Young rats are also less neophobic and more willing to sample new foods (Steinert et al. 1980). Kovalcik and Kovalcik (1986) reported that heifers may be able to learn about feeds more quickly than mature cows, yet their long-term memory is less stable. Thorhallsdottir et al. (1990a) presented conclusive evidence that lambs extinguished aversions to calf manna ${ }^{\mathbf{R}}$ in a 2-choice social facilitation trial, while their mothers retained the aversion. Aversions created in mature animals may be more resistant to extinction than in younger animals.

\section{Context of Learning}

All learning occurs in a cognitive or associative context of prior learning, and in an environmental context defined by the location, time, and specific features of the task at hand. All basic learning phenomena, including appetitive and aversion conditioning, have been shown to change with contextual manipulations (Balsam 1985, Best et al. 1977). Stimulus differences between the location where a response is learned and where it is expressed have a strong and usually detrimental effect (Miller and Schachtman 1985). Thus, food aversions formed in a pen may extinguish when animals are taken to the field.

Our experiment with social facilitation (Ralphs and Olsen 1990) is a classic example of an aversion extinguishing in the field, but renewing when the heifers were returned to the pen and the original context where the aversion was created. Archer et al. (1985) reported a similar response in rats averted to saccharin. The aversion was maintained while in the training context, but extinguished when the rats were moved to a new context. However, the aversion renewed and the rats refused to drink saccharin when returned to the original training context. Other types of learning have manifested a renewal when animals are placed in the context in which the response originally was learned (Bouton nd Bolles 1985, Cun- 
ningham 1979, Welker and McAuley 1978). The taste-illness association is not forgotten in extinction even though the outward behavior of avoiding the food is not manifest. Several theories have been proposed to explain this phenomena (Rescorla and Heth 1975, Miller and Schachtman 1985, Bouton and Bolles 1985).

Although taste is the primary sense involved in creating an aversion, the environmental context can influence the strength and retention of the aversion (Archer et al. 1985). It is necessary to utilize this relationship to strengthen, rather than hinder, the aversion. Lubow et al. (1976) proposed that learning is stronger when either the stimulus or the environment is novel relative to each other. That is, the aversion is stronger if a novel food is presented in a familiar environment; or a familiar food is presented in a novel environment. Kruz and Levitsky (1982) tested this hypothesis in rats and found the first premise to be true. The aversion was strongest when a novel food was presented in a familiar environment. However, no aversion was created when a familiar food was presented in a novel environment. In a novel environment, everything is novel and the stimulus is not salient. Mitchell et al. (1975) found that aversions to novel items were not learned in a less familiar environment.

Familiarity with the grazing environment may also be important in retaining an aversion. Naive animals rely on food cues from other animals as to what foods are safe or acceptable in a new environment (Provenza and Balph 1988). Thus, naive animals may be more susceptible to social facilitation in an unfamiliar environment. This appeared to be the case with our heifers (Ralphs and Olsen 1990). On the other hand, native animals that are familiar with the environment and have established preferences for the plants growing there, may be less susceptible to social facilitation and more likely to retain an aversion.

\section{Strengthening Averions}

To be practical, the aversion must persist. Very little food aversion research has dealt with the longevity of the aversion. Treatment of alcoholism with CFA is the only area where attempts have been made to maintain an aversion. Periodic booster sessions at predetermined intervals, or voluntary booster sessions whenever the subjects felt a need, were essential to maintain complete abstinence (Nathan 1985). Even with booster sessions, abstinence rate after 1 year was only $50-60 \%$. It is important to note, however, that alcoholism is a physiological dependency, not merely a taste preference.

Burritt and Provenza (1990b) were successful in reinforcing lambs' aversion to the mountain mahogany (Cercocarpus montanus Rat). Three month-old lambs were averted to the shrub and then held over until the next year. The aversion persisted to a degree when tested 1 year later (intake of mountain mahogany was about a third of nonaverted controls), although total abstinence was not maintained. However, with 1 follow-up dose of $\mathrm{LiCl}$ following consumption of the shrub, near total abstinence was maintained over 7 persistence trials throughout the summer.

\section{Future Research}

Conditioned food aversion learning in domestic livestock is a new field of study (Zahoric and Houpt 1977). To be practical, CFA must persist in a complex vegetation community in the field, and often in the social context of other animals eating the averted food. Several questions must be resolved before CFA can be recommended as a practical management tool. First, we must determine the optimum level of emetic required to maintain an aversion. In other words, how sick must an animal get in order to create a lasting aversion towards a food. The optimum age of conditioning for cattle and sheep must also be determined. Based on work by Thorhallsdottir et al. (1990a), mature animals may be less influ- enced by social facilitation, and thus more likely to retain an aversion.

Novelty of a food is a major requirement in creating a strong aversion. Familiarity with the grazing environment is also important in retaining the aversion. This creates a paradox since animals familiar with the grazing environment may also be familiar with larkspur. Two approaches are proposed to resolve this paradox. The novelty requirement could be used advantageously by averting naive replacement heifers which are unfamiliar with larkspur and the vegetation community where it grows. Averting them to larkspur and grazing them separately for the first year would allow them to develop feed preferences in a new environment without the influence of social facilitation. The second approach is to create aversions and strengthen them in native mature cattle that are familiar with the subalpine environment and vegetation community. Mature animals may be more resistant to social facilitation in a familiar environment, but creating and maintaining an aversion to larkspur as a familiar food may be more difficult.

The use of larkspur alkaloids as the emetic or aversive agent requires further study. Larkspur alkaloids were as effective as $\mathrm{LiCl}$ in creating an aversion (Olsen and Ralphs 1986), but the alkaloid extract is toxic, messy, and difficult to handle. However, alkaloids offer the advantage of being indigenous in the plant, and would provide internal feedback if the animal did subsequently consume larkspur in the field.

An intriguing application of CFA is the possibility of averted mothers passing the aversion to their offspring through social learning. Thorhallsdottir et al. (1990b) reported that young lambs (8 weeks old) avoided eating foods their mothers were averted to, and their rejection of the food lasted over 3 months following weaning. Mirza and Provenza (1990) reported similar results in lambs whose mothers were averted to mountain mahogany. Such a possibility offers the potential for modifying food preferences of an entire social group through succeeding generations.

If these obstacles to maintaining averions under field grazing conditions can be overcome, conditioned food aversion may be an effective tool in reducing livestock losses to palatable poisonous plants. Livestock could be trained to avoid eating specific plants, and then be allowed to graze infested ranges or pastures without restrictions of timing, loss of desirable forage quality, or costly control measures. Practicality or cost of creating aversions have not been investigated yet.

\section{Literature Cited}

Andrews, E.A., and N.S. Braveman. 1975. The combined effects of dosage level and interstimulus interval in the formation of one trial poison-based aversions in rats. Anim. Learn. \& Behav. 3:287-289.

Archer, T., P.O. Sjoden, and L.G. Nilsson. 1985. Contextual control of taste- aversion conditioning and extinction. p. 225-271. In. P.D. Balsam and A. Tomie (eds.), Context and learning. Lawrence Erlbaum Assoc., Hillsdale, N.J.

Balsam, P.D. 1985. The functions of context in learning and performance. p. 1-21. In: P.D. Balsam and A. Tomie (eds.), Context and learning Lawrence Erlbaum Assoc., Hillsdale, N.J.

Bermudez-Rattoni, F., M.A. Sanchez, J.L. Perez, D.L. Forthman, and J. Garcia. 1988. Odor and taste aversions conditioned in anesthetized moles. Behav. Neurosci. 102:726-732.

Bernstein, I.L. 1985. Learned food aversions in the progression of cancer and its treatment. p. 365-380. In: N.S. Braveman and P. Bronstein (eds.), Experimental annols assessments and clinical applications of conditioned food aversions. New York Acad. Sci., Vol. 433, New York.

Best, M.R., and L.M. Barker. 1977. The nature of learned safety and its role in the delay of reinforcement gradient. p. 295-325. In: L.M. Barker, M.R. Best, and M. Domjan (eds.), Learning mechanisms in food selection. Baylor Univ. Press, Waco, Tex.

Best, P.J., M.R. Best, and S. Henggeler. 1977. The contribution of environmental non-ingestive cues in conditioning with aversive internal consequences. p. 371-389. In. L.M. Barker, M.R. Best, and M. Domjan (eds.), Learning mechanisms in food selection. Baylor Univ. Press. 
Bouton, M.E., and R.C. Bolles. 1985. Contexts, event-memories, and extinctions. p. 133-166. In: P.D. Balsam and A. Tomie (eds.), Context and learning. Lawrence Erlbaum Assoc., Hillsdale, N.J.

Braveman, N.S., and P. Bronstein. 1985. Experimental assessments and clinical applications of conditioned food aversions. Animals. New York Acad. Sci. Vol. 443.

Bravemen, N.S., and J. Crane. 1977. Amount consumed and the formation of conditioned taste aversions. Behav. Biol. 21:470-477.

Burritt, E.A., and F.D. Provenza. 1989. Food aversion learning: conditioning lambs to avoid a palatable shrub (Cercocarpus montanus). J. Anim. Sci. 67:650-653.

Burritt, E.A., and F.D. Provenza. 1990a. Ability of lambs to learn with a delay between ingestion and consequences given meals containing novel and familiar foods. Appl. Anim. Behav. Sci. (Submitted).

Burritt, E.A., and F.D. Provenza. 1990b. Food aversion learning in sheep: persistence of conditioned taste aversions to palatable shrubs (Cercocarpus montanus and Amelanchier alnifolia). J. Anim. Sci. 68:1003-1007.

Cunningham, C.L. 1979. Alcohol as a cue for extinction: State dependency produced by conditioned inhibition. Anim. Learn. \& Behav. 7:45-52.

Domjan, M., and N. Wilson. 1972. Contribution of ingestion behaviors to taste aversion learning in the rat. J. Compar. and Physiol. Psychol. 80:403-412.

Dragoin, W.B. 1971. Conditioning and extinction of taste aversions with variations in intensity of the CS and UCS in two strains of rats. Psychon. Sci. 22:303-304

du Toit, J.T., F.D. Provenza, and A. Nastis. 1990. Conditioned food aversions: how sick must a ruminant get before it learns about toxicity in foods? Ethology (In press).

Everist, S.L. 1981. Poisonous plants of Australia. Angus and Robertson, Sydney, Australia.

Fenwick, S., P.J. Miluka, and S.B. Klein. 1975. The effect of different levels of pre-exposure to sucrose on the acquisition and extinction of a conditioned aversion. Behav. Biol. 14:231-235.

Franchina, J.J., and S.W. Horowitz. 1982. Effects of age and flavor preexposures on taste aversion performance. Bull. Psychonomic Soc. 19:41-44.

Galef, B.G., Jr. 1986. Social interaction modifies learned averions, sodium appetitie, and both palatability and handling-time induced dietary preference in rats (Rattus norvegicus). J. Comp. Psychol. 100:432-439.

Galef, B.G., Jr. 1988. Imitation in animals: history, definition, and interpretation of data from the psychological laboratory. p. 3-21. In: T.R. Zentall and B.G. Galef Jr., (eds.), Social learning psychological and biological perspectives. Lawrence Erlbaum Assoc., Hillsdale, N.J.

Garcia, J. 1989. Food for Tolman: cognition and cathexis in concert. p. 45-85. In: T. Archer and L. Nilsson (eds.), Aversion, avoidance, and anxiety, Lawrence Erlbaum Assoc., Hillsdale, N.J.

Garcia, J., F.R. Ervin, and R.A. Koelling. 1966. Learning with prolonged delay of reinforcement. Psychon. Sci. 5:121-122.

Garcia, J., W.G. Hankins, and J.D. Coil. 1977. Koalas, men, and other conditioned gastronomes. p. 195-218. In: N.W. Milgram, L. Krames, and T.M. Alloway (eds.), Food aversion learning. Plenum Press, New York.

Garcia, J., and M.D. Holder. 1985. Time, space and value. Human Neurobiol. 4:81-89.

Garcia, J., D.L. Kimeldorf, and E.L. Hunt. 1956. Conditioned responses to manipulative procedures resulting from exposure to gamma radiation. Radiation Res. 5:79-87.

Garcia, J., P.S. Lasiter, Bermudez-Rattoni, and D.L. Deems. 1985. A general theory of aversion learning. p. 8-21. In: N.S. Braveman and P. Bronstein (eds.), Experimental assessments and clinical applications of conditioned food aversions. New York Acad. Sci., Vol. 443, New York.

Grote, Jr., F.W., and R.T. Brown. 1973. Deprivation level affects extinction of conditioned taste aversion. Learning and motivation 4:314-319.

Guanowsky, V., J.R. Misanin, and D.C. Riccio. 1983. Retention of conditioned taste aversion in weanling, adult and old-age rats. Behav. and Neural Biol. 37:173-178.

Gustavson, C.R., and J.C. Gustavson. 1985. Predation control using conditioned food aversion methodology: theory, practice, and implications. p. 348-356. In: N.S. Braveman and P. Bronstein (eds.), Experimental assessments and clinical applications of conditioned food aversions. Annals New York Acad. Sci., New York.

Johnson, J.H., H.R. Crookshank, and H.E. Smolley. 1980. Lithium toxicity in cattle. Vet. Human Toxicol. 22:248-251.

Kalat, J.W., and P. Rozin. 1973. "Learned safety" as a mechanism in long-delay taste-aversion learning in rats. J. Compar. and Physiol. Psychol. 83:198-207. ovalcick, K., and M. Kovalcik. 1986. Learning ability and memory testing in cattle of different ages. Appl. Anim. Behav. Sci. 15:27-29.

Kruz, E.M., and D.A. Levitsky. 1982. Novelty of contextual cues in taste aversion learning. Anim. Learn. Behav. 10:229-232.

Lane, M.A., M.H. Ralphs, J.D. Olsen, F.D. Provenza, and J.A. Pister. 1990. Conditioned taste aversion: potential for reducing cattle loss to larkspur. J. Range Manage. 43:127-131.

Logue, A.W. 1985. Conditioned food aversion learning in humans. p. 316-329. In: N.S. Braveman and P. Bronstein (eds.), Experimental assessments and clinical applications of conditioned food aversions. Ann. New York Acad. Sci., Vol. 443. New York.

Lubow, R.E., R. Bathsheva, and M. Alek. 1976. The context effect: the relationship between stimulus preexposure and environmental preexposure determines subsequent learning. J. Exp. Psychol. 2:38-47.

Marsh, G.D., and A.B. Clawson. 1916. Larkspur poisoning of livestock. USDA Bull. 365 .

Miller, R.R., und T.R. Schachtman. 1985. The several roles of context at time of retrieval. p. 167-194. In: P.D. Balsam and A. Tomie (eds.), Context and learning. Lawrence Erlbaum Assoc., Hillsdale, N.J.

Mirza, S.N., and F.D. Provenza. 1990. Preference of the mother affects selection and avoidance of lambs differing in age. Appl. Anim. Behav. Sci. (In press).

Mitchell, D., E.H. Kirschbaum, and R.L. Perry. 1975. Effects of neophobia and habituation on the poison-induced avoidance of exteroceptive stimuli in the rat. J. Exp. Psychol. 104:47-55.

Nachman, M., and J.A. Ashe. 1973. Learned taste aversion in rats as a function of dosage, concentration, and rate of administration of $\mathrm{LiCl}$. Physiol. Behav. 10:73.

Nachman, M., J. Rauschenberger, and J.H. Ashe. 1977. Stimulus characteristics in food aversion learning. p. 105-131. In: N.W. Milgram, L. Krames, and T.M. Alloway (eds.), Food aversion learning. Plenum Press, New York

Nathan, P.E. 1985. Aversion therapy in the treatment of alcoholism: success and failure. p. 357-364. In: N.S. Braveman and P. Bronstein (eds.), Experimental assessments and clinical applications of conditioned food aversions. Ann. New York Acad. Sci., Vol. 443, New York.

Olsen, J.D., and M.H. Ralphs. 1986. Feed aversion induced by intraruminal infusion with larkspur extract in cattle. Amer. J. Vet. Res. 47:1829-1833.

Olsen, J.D., M.H. Ralphs, and M.A. Lane. 1989. Aversion to eating poisonous larkspur plants induced in cattle by intraruminal infusions with lithium chloride. J. Anim. Sci. 67:1980-1985.

Pelchat, M.L., and P. Rozin. 1982. The special role of nausea in the acquisition of food dislikes in humans. Appetite. 3:341-351.

Pfister, J.A., M.H. Ralphs, and G.D. Manners. 1988. Cattle grazing tall larkspur on Utah mountain rangeland. J. Range Manage. 41:118-122.

Provenza, F.D. 1987. Research to change livestock appetites. Utah Sci. 48:141-143.

Provenza, F.D., and D.F. Balph. 1988. Development of dietary choice in livestock on rangelands and its implications for management. J. Anim. Sci. 66:2356-2368.

Provenza, F.D., J.A. Pfister, and C.D. Cheney. 1990. Mechanisms of learning in diet selection with reference to phytotoxicosis in herbivores. J. Range Manage. (In press).

Ralphs, M.H., and J.D. Olsen. 1990. Overcoming the influence of social facilitation in training cattle to avoid eating larkspur. J. Anim. Sci. (In press).

Rescorla, R.A., and C.D. Heth. 1975. Reinstatement of fear to extinguished conditioned stimulus. J. Exper. Psychol.: Anim. Behav. Process. 1:88-96.

Revusky, S., L.A. Parker, J. Coombes, and S. Coombes. 1976. Rat data suggest alcoholic beverages should be swallowed during chemical aversions, not just tasted. Behav. Res. \& Therapy. 14:189-194.

Revusky, S., R.W. Pohl, and S. Coombes. 1980. Flavor aversions and deprivation state. Anim. Learn. and Behav. 8:543-549.

Riley, A.L., and D.L. Tuck. 1985. Conditioned taste aversion: a behavioral index of toxicity. p. 272-292. In: N.S. Braveman and P. Bronstein (eds.), Experimental assessments and clinical application of conditioned food aversion. Ann. New York Acad. Sci., Vol. 443, New York.

Rozin, P., and J.W. Kalat. 1971. Specific hungers and poison avoidance as adaptative specializations of learning. Psychol. Rev. 78:459-485.

Rozin, P., and D. Zellner. 1985. The role of Pavlovian conditioning in acquisitions of food likes and dislikes. p. 189-202. In: N.S. Braveman and $P$. Bronstein (eds.), Experimental assessments and clinical application of conditioned food aversion. Ann. New York Acad. Sci., Vol. 443, New York. 
Shumake, S.A., R.T. Sterner, S.E. Gaddis, and K.A. Crane. 1982. Conditioned taste aversion in Philippine rice rats (Ratus mindanensis): comparisons among drugs, dosages, modes of administration, and sexes. Anim. Learn. and Behav. 10:499-504.

Smith, J.C. 1985. Application of conditioned food aversion methodology. p. 308-315. In: N.S. Braveman and P. Bronstein (eds.), Experimental assessments and clinical applications of conditioned food aversions. Ann. New York Acad. Sci., Vol. 443, New York.

Springer, A.D., and S.M. Fraley. 1981. Extinction of a conditioned taste aversion in young, mid-aged, and aged C57/BL6 mice. Behav. Neural Biol. 32:282-294.

Squibb, R.C., F.D. Provenza, and D.F. Balph. 1990. Effect of age of exposure on consumption of a shrub by sheep. J. Anim. Sci. 68:987-997.

Steinert, P.A., R.N. Infurna, and N.E. Spear. 1980. Long-term retention of a conditioned taste aversion in preweanling and adult rats. Anim. Learn. Behav. 8:375-381.

Testa, T.J., and J.W. Ternes. 1977. Specificity of conditioning mechanisms in the modification of food preferences. p. 229-253. In: L.M. Barker, M.R. Best, and M. Domjan (eds.), Learning mechanisms in food selection. Baylor Univ. Press, Waco, Tex.

Thorhallsdottir, A.G., F.D. Provenza, and D.F. Balph. 1987. Food aversion learning in lambs with or without a mother: discrimination, novelty and persistence. Appl. Anim. Behav. Sci. 18:327-340.

Thorhallsdottir, A.G., F.D. Provenza, and D.F. Balph. 1990a. Social influences on conditioned food aversions in sheep. Appl. Anim. Behav. Sci. 25:45-50.
Thorhallsdottir, A.G., F.D. Provenza, and D.F. Balph. 1990b. The role of the mother in the intake of harmful foods by lambs. Appl. Anim. Behav. Sci. 25:35-44.

Welker, R.L., and K. McAuley. 1978. Reductions in resistance to extinction and spontaneous recovery as a function of changes in transportational and contextual stimuli. Anim. Learn. Behav. 6:451-457.

Wellman, P.J., and C.G. Boiseard. 1981. Influence of fluid deprivation level on the extinction of conditioned taste aversion induced by amphetamine in famale rats. Physiol. Psychol. 9:281-284.

Zahorik, D.M., and K.A. Houpt. 1977. The concept of nutritional wisdom: applicability of laboratory learning models to large herbivores.p. 45-67. In: L.M. Barker, M.R. Best, and M. Domjan (eds.), Learning mechanisms in food selection. Baylor Univ. Press.

Zahorik, D.M., and K.A. Houpt. 1981. Species differences in feeding strategies, food hazards, and the ability to learn food aversions. p. 289-310. In: A.C. Kamil and J.D. Sargent (eds.). Foraging behavior, Garland, New York.

Zajonc, R.B. 1965. Social facilitation. Science 149:269-274.

Zajonc, R.B. 1968. Attitudinal effects of mere exposure. J. Personal. Social Psych., Monogr. Suppl. 9:1-27.

Statement of Ownership, Management, and Circulation

(Act. of August 12, 1970, Sec. 3685, Title 39, United States Code)

1. Title of Publication: Journal of Range Management

2. Date of Filing: September 30, 1991

3. Frequency of Issue: Bimonthly

4. Location of Office of Publication: 1839 York Street, Denver, Colo. 80206

5. Location of General Business Office: Same

6. Name and Address of:

Publisher: Society for Range Management, 1839 York Street, Denver, Colo. 80206

Editor: Gary Frasier, 1300 Wheatridge Court, Loveland, Colo. 80537.

Managing Editor: Peter V. Jackson III, 1839 York Street, Denver, Colo. 80206

7. Owner: Society for Range Management, 1839 York Street, Denver, Colo. 80206

8. Known Bondholders, Mortgagees, etc.: Wyatt Company, 1850 M. Street NW \#700, Washington, DC 20036

9. For Completion by Nonprofit Organizations Authorized to Mail at Special Rates: The purpose, function, and nonprofit status of this organization and the exempt status for Federal income tax purposes have not changed during preceding 12 months.

10. Extent and Nature of Circulation
A. Total copies printed
B. Paid Circulation
1. Dealers, counter sales
2. Mail subscriptions
C. Total paid circulation
D. Free distribution
E. Total distribution
F. Copies not distributed
G. Total

I certify that the statements made by me abc

$\begin{array}{cc}\text { Avg. for } & \begin{array}{c}\text { Actual for } \\ \text { issue nearest } \\ \text { filing date }\end{array} \\ 5,824 & 5,665 \\ & \\ 0 & 0 \\ 5,083 & 5,128 \\ 5,083 & 5,128 \\ 14 & 14 \\ 5,097 & 5,142 \\ 727 & 523 \\ 5,824 & 5,665\end{array}$
complete.-Peter V. Jackson, Managing Editor. 